皮膜化成とを同時に行なう方法を発表している。特許明 細書1)にもとづいて私どもが実験したところによると， 薄いリン酸鉄皮膜を生成するものである。

ここ三年来全く新しいリン酸鉄皮膜法がわが国でも登 場してきた。これは昔のコスレット法とは趣きを異にし， 脱脂と皮膜化成とを同時に行なうものである。生成皮膜 は $\gamma \mathrm{Fe}_{2} \mathrm{O}_{3}$ と $\mathrm{FePO}_{4} \cdot 2 \mathrm{H}_{2} \mathrm{O}$ または $\mathrm{Fe}_{2}\left(\mathrm{PO}_{4}\right)_{3} \cdot x \mathrm{H}_{2} \mathrm{O}$ と の混合した組成分で黄色ないし青色を呈する。皮膜重量 は0.4 2 $\mathrm{g} / \mathrm{m}^{2}$ で従来のリン酸互鉛系皮膜に比べかなり 薄い。けれども前述のリン酸系洗浄剤で生成するリン酸 鉄よりもかなり厚く，サビ止效果もすぐれている。この リン酸鉄皮膜は非晶質であるから，材料が折曲ゲ，衝撃 などで変形しても皮膜がこわれることがないっそれゆえ 塗膜付着試験できわめてよい成績を示している。この新 しいリン酸鉄皮膜は金属塗装前処理の作業標準を規定し

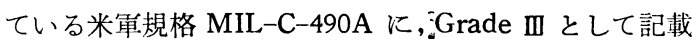
されている。なお新しいりン酸鉄皮膜用には浸セキ法用 およびスプレー法用に種々の処理剂が七夫されている。

\section{3. リン酸塩皮膜の塗膜付着性の改善}

鉄鋼製品の塗装下地にリン酸塩皮膜が施されることは 今日では工業常識となっている。この皮膜の主な役割 は下地のサビ止メであるが，冷延薄鋼板製品となると塗 膜の付着性が大いに問題となる。元来, リン酸盐皮膜は 結晶質でその表面は粗晶であって, 塗料をよく吸い込 み, 叙膜は結晶のすき閒に強固な足掛かりを得て, きわ めてよく付着していることは確かであるが, 折曲ゲ, ェ リキャン，衝撃などの材料に变形を来たす塗膜付着試験 を行ならと，必ずしもよい成績を示さないことも事実で ある。これは皮膜が前述のよ5に結晶の集積したものか ら成るので, 上述のような变形試験に耐えないわけであ る。この傾向は当然皮膜が厚くなるほど大きい。経験に よると塗膜付着試験ではリン酸塩皮膜の結晶は微細なる の汪どよく，また厚サは皮膜重量で $3 \mathrm{~g} / \mathrm{m}^{2}$ 以下の薄い ものがよい。皮膜結晶のち密化にはアメリカのパーカー 会社が矼究した ICRA (Internal Crystal Refining Agent）とい5薬品を配合した皮膜処理剂が有効であ る。な扣前項で述べた新しいリン酸鉄皮膜は, 従来付着 性がよくないといわれていたヤシ油变性アミノアルキド 樹脂塗料に対しても優秀な付着性を示している2)。

\section{4. 最終洗浄水と塗膜ブリスター}

最近冷延薄鋼板製品の叙装は One coat one bake と か wet wet one bake とか，とにかく塗装回数が少なく なったことに起因すると思われるが，毎年夏季になると 塗装品表面にフクレ, 系状サビ, ブリスターなどの発生 問題が繰り返えされる。下地処理の良否がメラミン系樹
脂塗料で塗装した場合の塗膜ブリスター発生に対する影 響について試験を行なった。その概要を述べると下記の ようである。

（1）塗装についていえば，3回塗リ以上の場合はブリス ターの発生は見られない。

(2) リン酸塩皮膜については, 皮膜重量が約 $6 \mathrm{~g} / \mathrm{m}^{2}$ 以.1: あれば発生しない。

(3) リン酸塩皮膜が約 $4 \mathrm{~g} / \mathrm{m}^{2}$ 以下で塗装 2 回以下の場 合, 次のような時に再現性のあるブリスターが出る。 (a)指紋の付着したところ，(b) $50 \mathrm{ppm}$ 以上の塩素分 （NaCl としての）を含さ水で最終的に洗浄した場合 (c)蒸留水で洗った場合でも，タレが残って凝縮乾燥し た部位には発生する。水道水, $0.1 \%$ クロム酸水で洗 った時でも，もちろんタレが凝縮乾燥した部分には発 生する。(d) リン酸塩処理後の乾燥温度 $\left(100 \sim 200^{\circ} \mathrm{C}\right)$ は関係しない。

ブリスター発生問題については塗料扣よび塗装法が大 いに関係することはもちろんだが，下地処理についても， 最終的に純良な水で洗い，タレを残さず，もし残ったら エアで完全に吹き飛ばし，よく乾燥することが，この種 の事故発生を防止するうえに肝要なポイントである。ア メリカのある白動車ボデーの塗装工程でリン酸塩処理 後, 希ク口ム酸水で洗い, さらに脱イオン水のミストを 振りかけ洗いし，比較的高温で乾燥することにより，ブ リスター発生が防止できたという報告例がある3，なお 系状サビ発生再現試験について詳細な報告がある4)。

\section{5. 塗装下地をそなえた薄鋼板}

近時製鉄所では需要家に対するサービスとして塗装下 地をそなえた薄鋼板を生産している。またこれから生産 を計画しているところがある。

\section{5-1 ボンデ亜鉛板}

これは亜鉛引鉄板に薄いリン酸塩皮膜を施したもので ある。需要はまだそんなに延びていないらしい。

\section{5一2 ボンデ鋼板}

これはフラッシュ電気覀鉛板に薄いリン酸塩皮膜を施 したものである。現在約 3000 t/月生産されますます需要 が伸びつつある。

以上 2 品種とる数年前から生産されているが，アメリ カの ARMCO が 1938 年以来発展させてきたものそ同 品種である。亜鉛の表面には厚薄いずれでも容易にリン 酸塩皮膜を生成させることができるが，か酷な鉒膜付着 試験に耐えるための皮膜の性質の改善には将来より高度 の研究が必要であろう。

\section{5一-3 フリキ代用鋼板}

アメリカは第二次世界戦争の際, スズの節約を図るた めブリキ板にかわる表面処理鋼板を求めた。まず取り上 
げられたのがリン酸塩皮膜であって，これにワニスを溆 装し, 主として雑用カン（油, 洗剤, 乾燥食品, 野菜類） 用のブリキ板の代用に採用され，スズの節約に相当役立 ったとのことである, 現在は電気ブリキ板が安価に供給 されるので，リン酸塩皮膜板は実用になっていない。し かし別にクロム酸皮膜をベースとする表面処理鋼板が, 新しくブリキ代用として出現した。これはボンデライト XL 402 (Parker Rust Proof Co.), ハイナック (Heinz Manuf.Co. Philadel.) などの商品名で出ている。鉄鋼 を化学的に処理してクロム酸塩皮膜を生成させる方法は 古くから塗装下地として着目されていたが，実用の域に 達しなかった。前記 2 法はクロム酸と可溶性有機高分子 との組合せから成る液を鋼板に薄く塗布し，加熱して6 価クロムを 3 価クロムに還元するとともに無機化合物と 有機高分子化合物との結合した皮膜を構成させるもので 簡便迅速な処理で塗装下地用素地を得んとするものであ る。近く日本であある製鉄所で生産されるはずである。

\section{6. 非鉄金属の塗装前処理}

\section{6一1 要 鉛}

亜鉛およびその合金の塗装下地には普通クロメートま たはリン酸塩皮膜が施される。電気通信用機器の亜鉛メ ッキ品にはクロナク法が主として用いられるようであ る。電話器部品には, 電気通信研究所と各電話器メーカ 一との共同研究になるクロメート処理が採用されてい る6)。Chromizing と称するクロム酸単独水溶液による 簡単な処理が, 航空機部品にアメリカ航空機会社から指 定されている。クロメート処理とリン酸塩処理といずれ がすぐれているか，またその使いわけはどうか？，と の質問を受けることがある。これに関する比較試験をし た報告はあまりないし米軍規格でも確とした線は引いて いないようである。私の知るところでは，a）皮膜処理 によるZnの溶損はクロナク法またはクロマイジングに 比ベリン酸䘏皮膜処理の方が多い。b）塗装するまでに 時間のあるとき，すなわち皮膜処理だけで長期保存する 場合にはリン酸塩皮膜の方が耐える。c）业鉛ダイカス ト品にはリン酸塩皮膜の方が適している。クロメート処 理は終戦後宮田製作所を通じてアメリカのユニクロム法 が導入され、それを機に大いに発展してきたと思われる。

\section{6一2 アルミニウム}

アルミニウムおよびその合金の塗装前処理法について は多数の方法が提案され, 、ちいち枚挙にいとまがない ほどである。近年は圧倒的にクロメート皮膜法が世界的 に流行している。処理剤としてボンデライト700 Series, アロジン各種, イリダイト各種などの商品名で市場に出 ている。多数の特許方法があるが処理液の組成は大概 $\mathrm{CrO}_{4}{ }^{--}, \mathrm{F}^{-}$が主成分でこれに酸化剤および各種助剤が
添加されている。処理液にリン酸イオンを含む液からは 美しい緑色の比較的厚い皮膜ができる（ゆえにリン酸塩 皮膜に分類する人がある)。アメリカではこの緑色調を 生かし建築材料に応用している。リン酸イオンを含まな い処理液からは大概黄色調の皮膜ができる。純アルミは 黄金色となり，Cu を含を合金はややカッ色気味となる。 $\mathrm{Al}$ のクロメート皮膜の耐食性はかなりよく, 陽極酸化 皮膜 (硫酸法) に匹敵する。しかしこの皮膜は耐摩擦性 に乏しいので耐食皮膜として独立することはむずかし い。クロメート皮膜の塗膜付着性は厚膜はよくないよ5 である。私どもの実験によると一般に黄色クロメ一ト皮 膜は可溶性のクロム酸根を吸蔵していることがあり,こ の場合には付着性はよくない。フルミ軽金属に対する塗 装前処理に関しては古くは航空機のフロートなどの叙装 の際に，終戦後には船舶用軽金属委員会（軽金属協会） で，また，近くはバス車体軽量化委員会などで相当検討 されたわけであるが，塗料および塗装法の関係もありな かなか結論が出ない。アルミ軽合金の使用は, 船舶, 車 両, 建築方面に段々広まっているので, これが塗装前処 理の研究もますます盛んにならねばならないと思う。

\section{6一3 ママグネシウム合金}

わが国では以前，アセレン酸法，IG 法が規格となっ ていたが, 近時米軍規格にならったJIS H8651 (1958)が 制定されたので，塗装前処理はこれによることとなる。 私どもの経験では，マグネ合金の化学処理は各工程を紐 心の注意をもって行ない, 洗い水むよく吟味しないと所 期の耐食皮膜は得られない。また表面の粗度が耐食性に 大いに関係するように思う。

\section{6一-4 黄 銅}

黄銅製品（例：電話器ダイヤル）にも塗装されること があり，前処理が必要である。これまではサンドブラス トまたは電気銅メッキを行ない粗面として塗膜の付着を よくしていた。段々製品が量産化されるに従い, 化学処 理に上る方法が要求されてきた。一時硫化物皮膜が採用 されたらしいが最近では亜酸化銅または黒色酸化銅皮膜 が施されその上に塗装される。 $4: 6,3.5: 6.5,3: 7$ 黄 銅により，それぞれ化学作用が異なる。銅分の多いるの は黒色酸化銅，少ないるのは亜酸化銅皮膜が適する。こ

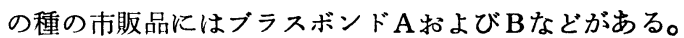

\section{文献}

(1) U. S P. 2789070

(2) 関西ペイント報告, 未発表

(3) Gerand H. Poll, Products Finishing, 11, 51 (1957)

(4) 関西ペイント, 塗料の研究, 41, 1 (1960)

(5) Iron Age, 6, June, 106 (1957)

(6) 表面処理研究会, クロメ一ト处理, 科学新興社刊 (1955) 